\title{
A PRELIMINARY REPORT ON THE PREY OF THE EURASIAN EAGLE-OWL (виво виво) IN AND AROUND PONDICHERRY
}

\author{
Mario Eric Ramanujam
}

Gratitude Avian Rehabilitation, Auroville, Pondicherry 605101, India.

Email: gratitude@auroville.org.in

\begin{abstract}
An effort was made to identify the prey base of Bubo bubo by the systematic analysis of regurgitated pellets found in and around the resting areas of two adult owls in the Ousteri and Pitchandikulam scrub jungles.

\section{Keywords}

Bubo bubo, Eurasian Eagle-Owl, prey, regurgitated pellets
\end{abstract}

\section{Introduction}

The prey of the Eurasian Eagle-Owl, Bubo bubo has been well documented by researchers in Europe as is evident from studies conducted by Curry-Lindahl in Sweden, Uttendorfer in the Carpathians (Anon, 1970) and Bayle (1994) in France (Anon, 1994). In India only general references by Ali and Ripley (1969) and Ali (1996) exist.

This being only a preliminary report, many details (viz. speciesspecific identification of prey items, biomass, etc.) have still to be worked out and many ponderables remain (viz. rodent movements back and forth between fields and scrub, resultant effects on raptor populations, etc.)

\section{Methods}

Pellet analysis method (Errington, 1932) was followed. The Union Territorry of Pondicherry and its environs in Tamil Nadu still contain a few relatively undisturbed scrub jungles, eroded ravines and rocky hillocks in the vicinity of standing bodies of water - the habitat of Bubo bubo. Field studies from March 1998 to December 1999 centered on two such areas - Ousteri and Pitchandikulam. Two adult territorrial birds, one in Ousteri and the other in Pitchandikulam were monitored on a weekly basis.

Bird watching sessions once a week were concurrently held

Received 23 December 2000

Accepted 22 February 2001 along with pellet gathering exercises. The daytime resting places of the owls were identified and pellets (both whole and disintegrated) were gathered for analysis.

The pellets were submerged in a basin of water for 10 minutes or so and then placed on a newspaper to drain. The softened tissues were gently teased apart with tweezers and all bones and binding material sent for identification.

\section{Results}

A total of 361 prey items were identified. Out of these 199 $(55.12 \%)$ were rodents, $11(3.04 \%)$ were shrews, three bats (0.83\%), 49 birds (13.57\%), 21 monitor lizards (5.81\%), 36 colubrid snakes $(9.97 \%)$, and 42 batrachians $(11.63 \%)$.

While rodents (Indian Gerbil Tatera indica, Indian Bush Rat Golunda ellioti, Rats Rattus sp., Little Indian Field Mouse Mus booduga and Indian Mole-rat Bandicota bengalensis) were preyed on throughout the year, others accounting for nearly 41 per cent showed seasonal variations - the vast majority of birds were taken between September to February, monitor lizards from October to March, snakes from September to May and Batracians from September to December. Occassional prey (less than 4\%) - shrews and bats - were consumed between May and July. A diurnal bird of prey Accipiter sp. and Spotted Owlet Athene brama were also consumed.

No arthropod nor fish remains were identified; neither was there evidence of the owl preying on the Large Bandicoot-rat Bandicota indica, Indian Long-tailed Tree Mouse Vandeleuria oleracea and Black-naped Hare Lepus nigricollis.

\section{Discussion}

The role of owls as agents of control on rodent populations has been mentioned by many researchers (Adiar, 1892; Ali \& Ripley, 1969; Ali, 1996; Allen, 1924; Cahn \& Kemp, 1930; Fischer, 1893; Lockie, 1955; Mason \& Lefroy, 1912; McWilliam, 1941; Southern, 1954). Rodents did form a major prey base for Bubo bubo but it was definitely less effective as a pest control agent than the 
Barn Owl Tyto alba -- a single bird has been reported to consume three mice per day and a family of two adults and five chicks can consume 20 mice a day (King, 1995).

Lack of the Large Bandicoot-rat and the Indian Long-tailed Tree Mouse in pellets may be that these rodents occupy different habitats and do not come into contact with Bubo bubo. The hare may be too large and swift for the owl to capture, though the criteria remains in doubt.

The period of 'plenty' begins after the advent of the South West monsoons in September. At this time water bodies are full and attract migratory birds. Rain triggers breeding behaviour in batracians and they are active throughout the hours of darkness, monitor lizards hatch out (and are preyed upon until they are of acceptable size) and colubrid snakes are more active. This state of affairs lasts until March. It is reported that Bubo bubo breeds during this period (Ali \& Ripley, 1969) and if so is very apt.

Occassional prey items, consisting of shrews and bats, were taken during the lean periods - i.e., the hottest months. That bats could be dangerous if consumed whole is borne out by the report of the death of a Oriental Bay-Owl Phodilus badius picked up dead disclosing the cause to be the wing bone of the bat protruding through the stomach (Ali \& Ripley, 1969). An Accipiter and Spotted Owlet were also consumed during these months.

\section{Acknowledgements}

I am thankful to Yvonne Artaud, Shanta Neville, Dietra Claire Worden and Thomas for their support and encouragement. Special thanks to the fellow 'pellet pickers', especially for tolerating my peculiarities.

\section{References}

Adiar, P. (1892). The Short-eared Owl (Asio accipitrinus pallas) and Kestrel (Falco tinnunculus) in the role plague districts. Annals of Scotland Natural History Society 1-4: 210-231.

Ali, S. (1996). The Book of Indian Birds. $12^{\text {th }}$ revised edition. Oxford University Press. 184, 327

Ali, S. and S.D. Ripley (1969). Handbook of the Birds of India and Pakistan. Oxford University Press 3: 251, 254, 274, 275.

Allen, A.A. (1924). A contribution to the life history and economic status of the Screech Owl (Otus asio). The Auk 41: 1-16

Anon (1970). World of Wildlife: Animals of Moorland and Forest. Orbis Publishing London, pp. 237, 238.

Anon (1994). Science and Nature 49: 36

Cahn, A.R. and J.J. Kemp (1930). On the food of certain owls in east central Illinois. The Auk 47: 323-328

Errington, P.L. (1932). The pellet analysis method of raptor food habits study. Condor 32: 292-296.

Fisher, A.K. (1893). The hawks and owls of the United States in their relation to agriculture. United States Department of Agriculture Division Bulletin, 3:1-210

King, S. (1995). BBC Wildlife. January: 20.

Kumar, T.S. (1985). The Life History of the Spotted owlet (Athene brama brama, Temminck) in Andhra Pradesh. Monograph of Raptor Research Centre, Hyderabad: 209-213.

Lockie, J.D. (1955). The breeding habits and food of Short-eared Owls after a role plague. Bird Study 2: 53-69.

Mason, C.W. and H.M. Lefroy (1912). The food of birds of India. Memoirs of the Department of Agriculture, India. Entomology Series 3. $376 \mathrm{pp}$.

Mc William, J.M. (1941). On the relation of the Short-eared Owl to the common role. British Birds. 34: 203, 204.

Southern, H.N. (1954). Tawny Owls and their prey. Ibis 96: 384-410

Table 1. Month by month breakdown of the prey of Bubo bubo as evidenced by pellets examined.

\begin{tabular}{|c|c|c|c|c|c|c|c|c|c|c|c|c|c|c|c|c|c|c|c|c|c|c|}
\hline \multirow[b]{2}{*}{ Prey } & \multicolumn{10}{|c|}{1998} & \multicolumn{12}{|c|}{1999} \\
\hline & M & A & M & $\mathrm{J}$ & J & A & $S$ & 0 & $\mathrm{~N}$ & D & J & $F$ & M & A & $M$ & J & $\mathrm{J}$ & $A$ & S & 0 & $\mathrm{~N}$ & D \\
\hline Rodents & 9 & 12 & 10 & 9 & 7 & 13 & 1 & 9 & 12 & 7 & 8 & 9 & 15 & 9 & 18 & 11 & 8 & 5 & 5 & 5 & 9 & 8 \\
\hline Shrews & & & 6 & 1 & & & & & & & & & & & 1 & 1 & 2 & & & & & \\
\hline Bats & & & 1 & & & & & & & & & & & & & 1 & 1 & & & & & \\
\hline Birds & & 4 & $1^{*}$ & & & & 3 & 4 & 1 & 8 & 11 & 3 & & & 1 & 1 ** & & & 2 & 4 & & 6 \\
\hline Monitor Lizard & & & & & & & & 5 & & 1 & 5 & 1 & 2 & & & & & & & & 2 & 5 \\
\hline $\begin{array}{l}\text { Rear fanged non-venomous } \\
\text { snakes }\end{array}$ & 4 & & 1 & & & & 2 & 5 & 3 & 7 & 5 & 4 & 3 & & & & 1 & & & 1 & & \\
\hline Batracians & & & & & & & 4 & 3 & 12 & 5 & & & & & & & & & 2 & 1 & 6 & 9 \\
\hline
\end{tabular}

* Remains of Accipiter sp. ${ }^{* *}$ Remains of Athene brama 